\title{
Menjawab Tuduhan Inkoherensi Dari John Hick Terhadap Konsep Dwinatur Dalam Doktrin Inkarnasi Ortodoks
}

\author{
Answering John Hick's Incoherence Allegations Against \\ Dual-Nature Concept in the Orthodox Doctrine of Incarnation
}

\author{
Fitri Yuliana \\ Program Studi Magister Teologi Sekolah Tinggi Teologi SAAT, Malang \\ Korespondensi: fitriyuliana0402@gmail.com
}

\begin{abstract}
Abstrak: Dalam berbagai tulisannya, John Hick menyatakan bahwa kekristenan harus memikirkan ulang mengenai pernyataan keilahian Yesus sebagai Allah Anak yang berinkarnasi. Dalam pandangannya, dwinatur dalam diri Yesus adalah hal yang tidak dapat dipahami dengan akal sehat karena kedua natur itu saling berkontradiksi. Sebagai jalan keluar, Hick menawarkan konsep mitologisasi yang menyatakan bahwa inkarnasi Yesus sebagai Allah Anak adalah sebuah mitos belaka. Untuk menjawab hal itu, dalam makalah ini, penulis menggunakan pendekatan logika gabungan: relativity thesis (pernyataan relativitas), natural kind concept (konsep ciri alamiah), dan divine preconscious model (model bawah sadar ilahi). Dengan metode relativity thesis, penulis dapat menunjukkan kesalahan logika tuduhan inkoherensi dari Hick terhadap doktrin inkarnasi ortodoks. Sementara itu, pendekatan natural kind concept dapat membuktikan koherensi dari konsep dwinatur yang ada dalam diri Allah Anak sebagai inkarnasi Allah. Divine preconscious model dapat memberikan pijakan logis mengenai kemanunggalan Pribadi Yesus dengan dua natur yang ada di dalam diri-Nya, yang tidak saling berkontradiksi. Dengan gabungan ketiga pendekatan tersebut makalah ini menyajikan argumen yang kuat untuk membuktikan bahwa doktrin inkarnasi ortodoks bersifat koheren. Dengan demikian, kekristenan tidak perlu memberikan artikulasi ulang terhadap doktrin inkarnasi ortodoks dan juga tidak perlu memaknai doktrin tersebut sebagai sebuah mitos.
\end{abstract}

Kata-kata kunci: Inkarnasi, Dwinatur, Pribadi, Kesadaran, Bawah Sadar, Yesus Kristus, John Hick

Abstract: In his writings, John Hick states that Christianity must rethink the claim to the divinity of Jesus as God the Son Incarnate. In his view, the dual-nature in Jesus is something that cannot be understood with common sense because the two natures contradict each other. As a way out, Hick offers the concept of mythologization which states that Jesus incarnation as God the Son is a myth. To answer that, the author basing her argument on biblical statements and uses a combined logic approach: relativity thesis, natural kind concept, and divine preconscious model. With the method of relativity thesis, the author can point out the logic errors of incoherent accusations from Hick to the orthodox doctrine of incarnation. Meanwhile, the natural kind concept approach can prove the coherence of the dual-natures concept that exists in God the Son as an incarnation of God. The Divine preconscious model can provide a logical basis for the unity of the Person of Jesus with the two natures within Him, which do not contradict each other. With the combination of the three approaches, this paper presents a strong argument to prove that the orthodox doctrine of Christ incarnate is coherent. Thus, Christianity does not need to rearticulate the orthodox doctrine of incarnation and also should not interpret the doctrine as a myth.

Keywords: Incarnation, Dual-Natures, Person, Conscious, Preconscious, Jesus Christ, John Hick 


\section{PENDAHULUAN}

Apakah benar bahwa Yesus dari Nazaret adalah Allah yang mahakuasa, mahahadir, mahatahu dan kekal? Apakah benar bahwa bayi Yesus yang sedang ditimang-timang dalam asuhan Maria dan Yusuf adalah Tuhan yang menciptakan dan mengatur alam semesta dari tempat tidur-Nya? Apakah benar bahwa Si Tukang Kayu ini adalah Allah yang sudah ada sejak dari kekekalan? Bagaimana mungkin Allah dapat berbagian dalam kemanusiaan yang fana dan begitu terbatas? Bagaimana mungkin Allah, Sang Pencipta jagat raya mengambil bentuk di dalam ciptaan sebagai manusia dalam inkarnasi? ${ }^{1}$ Bagaimana menjelaskan ini semua? Pertanyaanpertanyaan tersebut sering kali diajukan oleh beberapa kalangan ketika mereka mempertanyakan sifat dwinatur yang ada dalam diri Yesus Kristus. Dari serentetan pertanyaan tersebut, beberapa pandangan menyimpulkan bahwa konsep dwinatur Yesus adalah konsep yang tidak koheren karena bersifat kontradiktif atau inkoheren. Salah satu tokoh yang menyetujui adanya inkoherensi dalam konsep dwinatur kristologi ortodoks adalah John Hick. ${ }^{2}$

Berangkat dari ketidaksetujuannya terhadap konsep dwinatur yang diformulasikan oleh konsili Chalcedon tersebut, Hick menggubah satu kristologi yang menurutnya lebih bersesuaian dengan akal sehat. ${ }^{3}$ Dalam doktrin kristologi yang dibangunnya, ia meluncurkan beberapa tuduhan terhadap doktrin inkarnasi ortodoks terkait beberapa isu penting

\footnotetext{
${ }^{1}$ Minggus Pranoto, "Perkembangan Doktrin Inkarnasi Kristus: Misteri Iman dan Dasar Keselamatan Manusia," Jurnal Abdiel 6 (Oktober 2015): 88.

${ }^{2}$ John Hick, "Jesus and the World Religion," dalam The Myth of God Incarnate (London: SCM, 1977), 178.

${ }^{3}$ Selain mempermasalahkan logika, kristologi Hick bermaksud mengakomodasi pemikiran pluralisme yang baginya lebih cocok dengan keadaan masa kini yang bersifat plural. Untuk diskusi lebih lanjut lihat Hidalgo B. Garcia, "Pluralisme Agama dan Paradoks Kasih Karunia: Mengenai Pemakaian Kristologi Donald Baillie oleh John Hick," Veritas: Jurnal Teologi dan Pelayanan 7, no. 2 (Oktober 2006): 1, https://doi.org/10.36421/veritas.v7i2.175.
}

seperti keabsahan status keilahian Yesus dan segala kontradiksi yang ada dalam konsep dwinatur Yesus. Untuk itu penulis akan menjawab tuduhan-tuduhan yang dilayangkan Hick terhadap doktrin kristologi ortodoks.

Makalah ini akan dibagi ke dalam empat bagian besar. Pertama, penulis akan memaparkan secara ringkas pandangan Hick mengenai doktrin inkarnasi ortodoks. Kedua, penulis akan menjawab keberatan Hicks atas doktrin inkarnasi ortodoks yang menurutnya tidak sesuai dengan hukum logika (tidak koheren). Ketiga, penulis akan menanggapi tuduhan kepura-puraan Yesus dalam inkarnasi. Pada bagian keempat, penulis akan menunjukkan bukti koherensi dari doktrin inkarnasi ortodoks.

\section{DOKTRIN INKARNASI ORTODOKS DALAM PANDANGAN JOHN HICK}

Pada era pramodern, pernyataan 'Yesus adalah Anak Allah' dalam doktrin inkarnasi ortodoks, diterima begitu saja secara devosional tanpa ada pertanyaan-pertanyaan logis terhadapnya. Tidak demikian pada era modern ini (bahkan pascamodern), menurut Hick, pernyataan semacam itu seharusnya dipertanyakan lebih lanjut baik secara empiris maupun metafisika, seperti: apakah pernyataan tersebut mengandung makna literal, metaforis, simbolis atau mitologis. ${ }^{4}$

Hick berpendapat bahwa konsep dwinatur Kristus dalam doktrin inkarnasi ortodoks yang menyatakan bahwa Yesus adalah manusia sepenuhnya dan Tuhan seutuhnya, bukanlah sebuah misteri ilahi melainkan suatu pernyataan yang dibuat oleh sekumpulan orang dalam Konsili Chalcedon yang berusaha untuk merumuskan identitas Yesus. ${ }^{5}$ Selain itu, menurut Hick, definisi tentang

\footnotetext{
${ }^{4}$ Hick, "Jesus and the World Religion," 177.

${ }^{5}$ John Hick, The Metaphor of God Incarnate (Louisville: Westminster John Knox, 1993), 48.
} 
Allah Anak yang berinkarnasi yang dicetuskan dalam Konsili Nicaea adalah satu cara untuk mengonsepkan ketuhanan Yesus yang kemudian diadopsi oleh dunia YunaniRomawi dan diwariskan kepada generasi masa kini. ${ }^{6}$ Pengangkatan seorang manusia kepada status ilahi inilah yang pada akhirnya menjadi dogma kekristenan ortodoks yang melihat Yesus sebagai Allah Anak yang berinkarnasi; Pribadi Kedua dalam diri Tritunggal yang hidup sebagai manusia; seperti yang tertuang dalam kredo Nicaea. ${ }^{7}$

Untuk menyanggah doktrin tersebut, Hick berusaha menghubungkan konsep dwinatur Yesus dengan mitologi. Menurutnya, dalam konteks mitologi, anggapan Yesus sebagai Anak Allah memunculkan ekspresi yang lebih jelas seperti yang tertulis dalam kredo Nicaea:

who for us men and for our salvation came down from the heavens and was made flesh of the Holy Spirit and the Virgin mary, and became man and was crucified for us under Pontius Pilate, and suffered and was burried, and rose again on the third day according to the Scriptures and ascended into the heavens and sitteth on the right hand of the Father, and cometh again with glory to judge living and dead, of whose kingdom there shall be no end. ${ }^{8}$

Menurut Hick, hal ini berarti bahwa doktrin yang menyatakan Yesus adalah Anak Allah hanyalah sebuah konsep mitologi. Cerita Anak Allah turun dari sorga dan menjadi bayi manusia adalah sebuah ekspresi mitologi. ${ }^{9}$ Ekspresi ini mempunyai pengaruh yang kuat di mana dengan kehadiran dari Sang Bayi ini, manusia seperti merasakan kehadiran Allah sendiri.

\footnotetext{
${ }^{6}$ Hick, "Jesus and the World Religion," 168

${ }^{7}$ Ibid., 171 .

${ }^{8}$ Ibid., 179 .

${ }^{9}$ Ibid., 184.
}

Dengan kata lain, menurut Hick, sangat masuk akal untuk menyatakan bahwa pokok utama dan nilai dari doktrin inkarnasi tidak bersifat indikatif melainkan ekspresif yaitu tidak untuk menyatakan fakta metafisika tapi untuk mengekspresikan penilaian dan membangkitkan respons dalam tindakan. ${ }^{10}$ Berkaitan dengan hal tersebut, Hick menjelaskan:

The doctrine of the incarnation is not a theory which out to be able to be spelled out but-in a term widely used throughout Christian history - a mistery. I suggest that its character is best expressed by saying that the idea of divine incarnation is a mythological idea. And I am using the term 'myth' in the following sense: a myth is a story which is told but which is not literally true, or an idea or image which is applied to someone or something but which does not literally apply, but which invites a particular attidude in its hearers. Thus the truth of a myth is a kind of practical truth consisting in the appropriateness of the attitude to its object. That Jesus was God the Son incarnate is not literally true, since it has no literal meaning but it is an application to Jesus of a mythical concept whose function is analogous to that of the notion of divine sonship ascribed in the ancient world to a king. ${ }^{11}$

Dari penjelasan di atas terlihat bahwa Hick memandang doktrin inkarnasi yang dideklarasikan oleh konsili Nicaea dan Chalcedon tidak seharusnya dimaknai secara metafisika namun metafora.

Dengan paradigma di atas, persoalan selanjutnya yang dipermasalahkan oleh Hick dalam doktrin inkarnasi ortodoks ialah pernyataan mengenai dwinatur dalam diri Yesus yang menurutnya tidak dapat dipahami dengan akal sehat karena kedua natur itu saling

\footnotetext{
${ }^{10}$ Ibid., 178.

${ }^{11}$ Ibid.
} 
berkontradiksi. Hick menjelaskan bahwa Pribadi Kedua yaitu Allah Anak yang terwujud dalam diri Yesus tidak pernah dapat dijelaskan secara koheren oleh kekristenan. Menurutnya, jika Yesus mempunyai dua natur, yaitu ilahi dan manusiawi yang keduanya tidak terpisahkan, maka tidak dapat dikatakan bahwa Yesus adalah manusia sejati sepenuhnya. ${ }^{12}$ Jawaban yang lazim diberikan oleh kekristenan adalah bahwa Yesus yang mengambil rupa seorang hamba telah mengosongkan diri-Nya sebagai Allah dan tidak menganggap kesetaraan dengan Allah sebagai hak milik yang harus dipertahankan. Terhadap pemikiran tersebut, Hick memberikan bantahan dengan mengatakan bahwa semakin Yesus mengosongkan diri-Nya sebagai Allah maka semakin berkurang natur ilahi-Nya sebagai inkarnasi Allah. ${ }^{13}$

Menurut Hick, doktrin dwinatur dari kalangan ortodoks ini sangat jauh dari memuaskan karena doktrin ini sendiri tidak mampu menjelaskan maknanya secara esensial. ${ }^{14}$ Hal itu ia jelaskan dalam tulisannya sebagai berikut:

Against these theories-which were wellmeant attempts to give meaning to the God-Man formula-orthodoxy insisted upon the two natures, human and divine, coinhering in the one historical Jesus Christ. But orthodoxy has never been able to give his idea any content. It remains a form of word without assignable meaning. For to say, without explanation, that historical Jesus of Nazareth was also God is as devoid of meaning as to say that this circle drawn with a pencil on paper is also a square. Such a locution has to be given semantic content: and in the case of the language of incarnation every content thus

\footnotetext{
${ }^{12}$ John Hick, "Incarnation and Atonement: Evil and Incarnation," dalam Incarnation and Myth: The Debate Continued (Grand Rapids: William B. Eerdmans, 1979), 83.

${ }^{13}$ John Hick, "Incarnation and Atonement: Evil and Incarnation," 83.

${ }^{14}$ Hick, "Jesus and the World Religion," 178.
}

far suggested has had to be repudiated. The Chalcedon formula, in which the attempt rested, merely reiterated that Jesus was both God and man, but made no attempt to interpret the formula. ${ }^{15}$

Tentang pandangan kenosis di atas, Hick menyatakan bahwa ada kontradiksi yang jelas di dalam doktrin kenosis, seperti yang dinyatakannya sebagai berikut:

And so the major kenotic theories speak not merely of concealment of divine attributes but of an actual divine self-emptying, self-retraction, divestment of powers, a shedding of absolute qualities in order to take on humanity - and yet without who does this ceasing to be fully and unequivocally God the Son. Clearly there is at least a seeming contradiction here; and as in the case of the two-natures christologies the question is whether sense can nevertheless be made of it. This is what the kenotic theorist try to do. In my opinion they do not succeed. They set forth the general idea of a radical divine self-giving, the Saviour coming to us in the humility of weakness, poverty and vulner-ability; and they show the religious value of such picture as a supreme manifestation of divine love. But when they come to the apparent contradiction of being who is God and yet lacks the attributes of God, all that they can do is to offer analogies which fail to reach the key issue, and then appeal to mystery. ${ }^{16}$

Jadi menurut Hick, Yesus yang mahakuasa yang secara sadar menahan diri-Nya untuk menggunakan kekuatan-Nya yang tidak terbatas; Yesus yang mahatahu namun berpura-pura menjadi manusia yang terbatas secara pegetahuan, tidak bisa disebut sebagai manusia biasa. ${ }^{17}$ Sebagai manusia super, Yesus tidak akan merasakan ketakutan dan

\footnotetext{
${ }^{15}$ Ibid.

${ }^{16} \mathrm{Hick}$, The Metaphor of God Incarnate, 62.

${ }^{17}$ Ibid.
} 
kecemasan seperti yang dirasakan manusia pada umumnya. Pencobaan dan misteri kematian yang harus dihadapi manusia menjadi sesuatu yang tidak nyata bagi Yesus. ${ }^{18}$

Selain itu, sebagai Allah, menurut Hick, Yesus tahu bahwa kematiannya bersifat sementara karena Yesus tahu bahwa sebagai Allah, Ia tidak akan mati. Oleh karena itu, menurut Hick, kematian Yesus tidak mempunyai makna yang signifikan. Lebih lanjut Hick menyatakan juga bahwa berkaitan dengan kematian Yesus, kekristenan kembali gagal untuk memberikan penjelasan yang memadai mengenai dwinatur Yesus. Hal ini ia tuliskan sebagai berikut:

God incarnate would know that his 'death' could only be temporary; for God cannot cease to be God, the eternal source of all life and being; and so to speak literally of his death is to speak without meaning. Indeed in earlier theology, to avoid undermining the very idea of God, some clutched at the desperate expedient of saying that qua God Jesus was not subject to death and that it was qua man that he was killed. But then we sunder the two natures and thereby destroy the idea of incarnation. How was God incarnate as Jesus of Nazareth if God did not undergo what Jesus underwent? ${ }^{19}$

Dari pemaparan di atas, nyata bagi Hick bahwa doktrin inkarnasi ortodoks merupakan doktrin yang tidak koheren karena di dalamnya terdapat banyak hal yang tidak dapat dijelaskan dengan logika yang benar.

\section{ISU LOGIKA DALAM DOKTRIN INKARNASI}

Pandangan Hick di atas sangat berbahaya bagi kekristenan. Argumen-argumen yang

\footnotetext{
${ }^{18}$ Ibid.

${ }^{19}$ Hick, "Incarnation and Atonement: Evil and Incarnation," 80.
}

dibangun berdasarkan beberapa fakta historis dan logika yang tampaknya benar, dapat mempengaruhi kepercayaan orang-orang Kristen kepada Kristus. Oleh karena itu, dalam bagian ini penulis akan menanggapi isu logika yang dilayangkan oleh Hick yang menyatakan bahwa doktrin inkarnasi tidak bersifat koheren.

Dwinatur Yesus merupakan suatu hal yang sangat sulit untuk dicerna dengan akal sehat karena dua natur yang terdapat di dalam diri Yesus tampak begitu berseberangan di mana satu natur bersifat ilahi sedangkan natur lainnya bersifat manusiawi. Natur ilahi mempunyai atribut-atribut yang jauh berbeda bahkan bertolak belakang dengan natur manusiawi di mana yang ilahi bersifat omnipotent (mahakuasa), omniscient (mahatahu), incorporeal (tidak mempunyai tubuh), impeccable (tidak dapat berbuat dosa), impassible (tidak dapat menderita), immutable (tidak berubah), eternal (kekal); sementara itu natur manusiawi bersifat terbatas dalam kuasa dan pengetahuan; mempunyai tubuh jasmani, dapat berbuat dosa, dapat merasakan derita, berubah-ubah dan tidak kekal. Hal ini menimbulkan kesulitan yang besar dalam memahami pernyataan dwinatur Yesus sebagai inkarnasi Allah. Anna Case-Winters menggambarkan kesulitan tersebut dengan jelas seperti yang ia tuliskan sebagai berikut:

Traditional Christology has had significant difficulty in articulating its ancient affirmation expressed in the definition of Chalcedon: "truly God, truly human ... two natures in one person." This claim has seemed at best paradoxical, at worst contradictory. How is it possible to make a non-contradictory affirmation of these Christological convictions? The challenge of coherency is heightened by the assumed "polar opposition" between God and all else ... this opposition is structured by assigning of metaphysical contraries to God and the world in binary opposition. The "infinite qualitative distinction" between 
Creator and created makes any joining of divine and human difficult to imagine. ${ }^{20}$

Oleh karena itu sepertinya sangatlah wajar apabila banyak orang (termasuk John Hick) menyatakan secara terang-terangan bahwa doktrin inkarnasi ortodoks yang mengklaim dwinatur Yesus merupakan doktrin yang inkoheren. Untuk menjawab persoalan tersebut penulis akan memaparkan kesalahan logika yang ada dalam tuduhan inkoherensi kristologi ortodoks. Selain itu penulis juga akan memberikan tanggapan atas kesalahan tersebut dan solusinya.

Tuduhan inkoherensi dalam doktrin inkarnasi muncul karena adanya konsep logika statement of identity. Statement of identity atau pernyataan identitas mempunyai peran penting dalam berbagai bidang ilmu, baik yang scientific (ilmiah) maupun nonscientific (tidak ilmiah) karena dari pernyataan identitas akan ditemukan relasi antara satu obyek dengan obyek lainnya. Dalam mengkaji logika mengenai inkarnasi Allah Anak, pernyataan identitas dapat menjadi alat yang berguna untuk menguraikan kekusutan logika yang seringkali menimbulkan perdebatan di berbagai kalangan. Pernyataan identitas yang mempunyai bentuk seperti pernyataan absolut dan identitas berupa angka, diatur oleh serangkaian prinsip atau hukum yang diantaranya adalah prinsip indiscernibility of identicals. ${ }^{21}$ Prinsip ini secara sederhana menyatakan bahwa obyek $\mathrm{x}$ identik dengan obyek y jika setiap sifat yang dimiliki obyek $\mathrm{x}$ juga dimiliki oleh obyek y dan demikian juga sebaliknya. Dengan kata lain prinsip ini menyatakan apabila obyek $\mathrm{x}$ tidak mempunyai properti yang sama dengan obyek y maka kedua obyek tersebut tidak bisa dikatakan identik.

\footnotetext{
${ }^{20}$ Anna Case-Winters, "Incarnation: In What Sense Is God Really 'With Us'?," European Journal for Philosophy of Religion 11, no. 1 (2019): 14.

${ }^{21}$ Thomas V. Morris, The Logic of God Incarnate (Eugene: Wipf \& Stock, 2001), 17.
}

Berdasarkan logika tersebut, doktrin inkarnasi diklaim sebagai doktrin yang tidak logis. Klaim utama dari doktrin inkarnasi menyatakan Yesus Kristus adalah Allah Anak yang merupakan Pribadi Kedua dari Allah Tritunggal; mempunyai dua natur yaitu natur ilahi dan manusiawi. Yang menjadi persoalan pokok dari pernyataan tersebut adalah ketidakcocokan antara properti yang dimiliki Yesus sebagai manusia dengan properti Pribadi Allah. Dengan demikian berdasarkan teori logika indiscernibility of identity, Yesus dan Allah tidak dapat dikatakan identik karena keduanya mempunyai sifat yang tidak sama. Oleh karena itu pernyataan bahwa Yesus adalah Allah Anak merupakan bentuk inkoherensi dalam logika dan patut dinyatakan sebagai pernyataan yang keliru.

Untuk menjawab tuduhan inkoherensi doktrin inkarnasi ini, penulis tidak akan menegasikan logika yang digunakan untuk menyatakan inkoherensi tersebut melainkan akan mengkritisi beberapa aturan atau prinsipprinsip yang menimbulkan kesulitan teologis. Dalam bukunya, The Logic of God Incarnate, Morris menguraikan kesalahan logika dari indiscernibility statement sebagai berikut. ${ }^{22}$ Ada empat pernyataan yang tampak tidak konsisten:

1. Hanya ada satu Allah.

2. Sang Bapa adalah Allah.

3. Sang Anak adalah Allah.

4. Sang Bapa bukanlah Sang Anak.

Dari empat kalimat di atas, pernyataan nomor dua dan tiga bersesuaian dengan pernyataan nomor satu namun tidak cocok dengan pernyataan nomor empat. Kendati demikian, bagi kekristenan, keempat pernyataan di atas diakui kebenarannya. Untuk memahami hal ini, pernyataan kedua dan ketiga harus dimaknai sebagai predikatif dan bukan identitas. Dengan melihat kalimat kedua dan ketiga sebagai predikatif maka kalimat pertama dan keempat merupakan pernyataan identitas. Untuk memperjelas

\footnotetext{
${ }^{22}$ Ibid., 26-32.
} 
hal ini, penulis akan menggunakan pendekatan relativitas identitas ${ }^{23}$ di mana satu pernyataan identitas, misal $\mathrm{x}$ adalah $\mathrm{y}$ atau $\mathrm{x}$ sama dengan $y$, dirasa masih belum lengkap karena ada pertanyaan lanjutan yang mengikuti seperti, "dalam hal apakah x sama dengan y?" Pernyataan selanjutnya juga dapat mengarah pada fakta bahwa $\mathrm{x}$ dapat sama dengan y dalam hal tertentu namun tidak sama dalam hal lainnya. Dengan metode pernyataan relativitas ini, doktrin inkarnasi akan dapat dipahami dengan lebih logis.

Kembali kepada keempat pernyataan di atas maka pernyataan nomor empat dapat dibenarkan apabila pernyataan tersebut merujuk kepada pribadi (person). Selain itu, pernyataan nomor empat juga akan bersesuaian dengan pernyataan nomor dua dan tiga meskipun kata predikatif yang digunakan dalam kalimat kedua dan ketiga adalah kata "Allah." Sementara itu, kalimat kedua dan ketiga tetap konsisten dengan kalimat pertama dan tidak bertentangan dengan kalimat keempat. Dengan demikian, penalaran ini membuat keempat pernyataan di atas menjadi dapat diterima sepenuhnya dengan akal sehat.

Kendati demikian, penggunaan metode relativitas identitas ini tampaknya tidak cukup untuk menjadi satu-satunya penopang dalam menjawab inkoherensi doktrin inkarnasi. Untuk itu penulis bermaksud menggandeng pendekatan metafisika dalam membedah tuduhan inkoherensi doktrin inkarnasi. Salah satu pandangan yang menarik dalam metafisika adalah pandangan fenomenalis yang menyatakan bahwa setiap obyek fisik identik dengan kumpulan data indera. ${ }^{24}$ Pandangan ini diperkuat oleh pandangan filosofi pikiran (philosophy of mind) yang menyatakan bahwa

\footnotetext{
${ }^{23}$ Pendekatan ini digunakan oleh A.P. Martinich dalam "Identity and Trinity," Journal of Religion, (April 1978): 169-181; Peter Geach, Logic Matters (Barkeley: University of California Press, 1980) 238-249; Nicholas Griffin, Relative Identity (Oxford: Clarendon Press, 1977).

${ }^{24}$ Ibid., 30 .
}

“mental states, events, or processes are identical with physical states, events or processes." 25

Lebih lanjut kaum fenomenalis ${ }^{26}$ menjelaskan bahwa pendekatan ini banyak bertentangan dengan metode indiscernibility requirement. Banyak obyek yang tidak dapat diidentifikasikan dengan metode indiscernibility. Obyek fisik merupakan obyek tiga dimensi sementara itu koleksi data indera tidak berbentuk tiga dimensi melainkan berbentuk privat. Selain itu ada banyak ciri lainnya dari suatu obyek yang merupakan bagian dari identitas obyek tersebut. Oleh karena itu, beberapa filsuf seperti James Cornman mengusulkan sebuah revisi terhadap prinsip indiscernibility mengenai pernyataan identitas. ${ }^{27}$ Usulan yang diajukan adalah " $\mathrm{x}=\mathrm{y}$ " akan dianggap sebagai pernyataan yang benar apabila terdapat kesamaan properti yang secara signifikan menyatakan identitas $\mathrm{x}$ dan $\mathrm{y}$.

Usulan perubahan formula prinsip discernibility ini dapat diaplikasikan ke dalam doktrin inkarnasi sebagai berikut. Dapat dikatakan bahwa banyak sifat manusia yang secara harafiah tidak dapat dinyatakan sebagai sifat Allah dan banyak pula karakteristik ilahi yang tidak dapat begitu saja dimiliki oleh manusia manapun. Jika semua perbedaan antara sifat ilahi dan manusiawi berdasarkan pada pemilahan ini maka pernyataan bahwa "Yesus adalah Anak Allah" dapat diterima dalam prinsip indiscernibility sehingga dapat dinyatakan sebagai klaim yang benar.

Karakteristik manusiawi yang ada dalam diri Yesus yang tampak bertentangan dengan

\footnotetext{
${ }^{25}$ Ibid.

${ }^{26}$ Beberapa fenomenalis yang dimaksudkan adalah James Cornman dengan karyanya "The Identity of Mind and Body," dalam The Mind-Brain Identity Theory, ed. C.V. Borst (London: Macmillan, 1970); dan Thomas Nagel, "Physicalism," dalam Materialism and The Mind-Body Problem, ed. David M. Rosenthal (Englewood Cliffs: Prentice hall, 1971).

${ }^{27}$ Morris, The Logic of God Incarnate, 31.
} 
natur keilahiannya dapat dipahami dengan cara sebagai berikut. Klaim keilahian Yesus membuat orang Kristen harus menyangkal bahwa Yesus tidak diciptakan karena natur keilahian Yesus akan memposisikan Yesus sebagai Sang Pencipta. Di sini tampak adanya kontradiksi dalam pribadi Yesus sebagai manusia seratus persen dan juga Allah seratus persen dalam hal status mengenai apakah Yesus diciptakan ataukah Dia Sang Pencipta. Untuk menelisik masalah ini (dan juga pertentangan sifat manusiawi dan ilahi yang lainnya) pertama-tama harus dibedakan dengan jelas antara konsep analitik, konsep kluster dan konsep ciri alami. Berkaitan dengan ciri kemanusiaan, konsep analitik menyatakan bahwa "manusia adalah makhluk ciptaan" di mana hal ini berarti makna konsep dalam predikat (makhluk ciptaan) diterangkan oleh makna dari konsep subyeknya (manusia). ${ }^{28}$ Sementara itu konsep kluster adalah konsep yang hanya berisi konsep-konsep lainnya. ${ }^{29}$ Sebagai contoh, dalam konsep kluster, kata "jejaka" mengandung konsep "berwujud laki-laki, dewasa, dan belum menikah." ${ }^{30}$ Yang terakhir adalah konsep ciri alami. Konsep ciri alami mendefiniskan makhluk hidup berdasarkan ciri-ciri alamiahnya. Sebagai contoh dalam menjelaskan konsep mengenai seekor harimau, pendeskripsian tidak dapat dibatasi pada karakteristik tertentu saja seperti: makhluk hidup yang mempunyai empat kaki, ekor, loreng dan hidup di iklim tropis. Penggambaran semacam ini akan mempersempit ruang lingkup jenis-jenis harimau karena ada berbagai macam varian yang kemungkinan tidak memiliki ciri seperti ciriciri yang disebutkan di atas.

\footnotetext{
${ }^{28}$ Thomas D. Senor, "The Incarnation and the Trinity," dalam Reason for the Hope Within, ed. Michael J. Murray (Grand Rapids: William B. Eerdmans, 1999), 246.

${ }^{29}$ Ibid., 247.

${ }^{30}$ Ibid. Konsep analitik akan menyatakan pernyataan yang cukup berbeda seperti: semua jejaka adalah laki-laki; semua jejaka adalah orang dewasa; dan semua jejaka tidak menikah.
}

Dari berbagai konsep yang dipaparkan di atas maka konsep mengenai kemanusiaan paling tepat dimaknai dalam konsep ciri alamiah dan bukan konsep kluster maupun konsep analitik. Mendukung hal ini, Thomas D. Senor menjelaskan kemanusiaan secara komprehensif seperti yang ia tuliskan sebagai berikut:

Whether or not humanity just is a natural
kind will be a matter of controversy. Argu-
ably part of what it is for something to be a
natural kind is for it to be the kind of thing
whose nature can be understood by the
natural sciences. Now if humans are purely
biological creatures, then we are natural
kinds. However, if mind/body dualism is
true and we have immaterial souls, then
there will be an important part of human
nature that will be outside the domain of
the empirical natural science.

Jika demikian, bagaimana merumuskan dengan masuk akal mengenai kemanusiaan Yesus yang bukan merupakan ciptaan? Dari konsep ciri alamiah di atas dapat disimpulkan bahwa manusia mempunyai ciri kemanusiaan tertentu yang dimiliki manusia pada umumnya namun tidak semua manusia memiliki ciri tersebut secara penuh. Ada sekelompok manusia tertentu yang tidak memiliki beberapa ciri umum yang dimiliki manusia kebanyakan. Kendati demikian, hal tersebut tidak serta merta menjadikan manusia tersebut tidak dapat digolongkan sebagai manusia karena mereka tidak memiliki ciri umum yang dimaksudkan..$^{32}$ Inilah kebenaran logis yang harus dipahami dengan jelas. Oleh karena itu, pemahaman ini juga berlaku untuk sosok Yesus. Meskipun Ia tidak pernah diciptakan, hal tersebut tidak serta-

\footnotetext{
${ }^{31}$ Ibid., 248.

${ }^{32}$ Sebagai contoh, salah satu ciri manusia pada umumnya adalah memiliki dua tangan dan dua kaki. Kendati demikian, orang-orang yang tidak mempunyai ciri tersebut tidak serta-merta bisa digolongkan sebagai bukan manusia. Orang-orang difabel yang tidak mempunyai dua tangan dan dua kaki tetaplah manusia.
} 
merta menegasikan kemanusiaan-Nya. Berkenaan dengan hal ini, Senor dengan cermat membedakan properti manusia ke dalam dua golongan yaitu yang bersifat common (umum) dan essential (penting). ${ }^{33}$ Properti umum manusia adalah karakteristik yang dimiliki semua manusia sedangkan properti esensial adalah karateristik yang harus dimiliki manusia. Dengan pemikiran ini, maka kemanusiaan Yesus yang berbeda dari manusia pada umumnya tidak bisa membuktikan bahwa Yesus bukan manusia karena kelayakan properti yang jadi pertimbangan secara logis untuk mengesahkan kemanusiaan Yesus hanya berdasarkan properti umum semata.

Jadi, sebelum wahyu khusus, manusia mungkin tahu tentang Allah dan manusia namun mereka tidak dapat dengan jelas memahami properti esensial manakah yang merupakan milik Allah dan properti esensial manakah yang merupakan ciri manusia. Dengan demikian, manusia hanya memiliki sebuah apriori yang terbatas mengenai sosok seperti apakah Tuhan dan manusia itu. Apriori akan keterbatasan manusia dalam mengenal Allah ini mengatakan apakah inkarnasi adalah sesuatu yang mungkin terjadi. Aposteriori bagi orang-orang yang mempercayai inkarnasi menyatakan bahwa inkarnasi adalah hal yang memungkinkan untuk dilakukan oleh Tuhan. Dengan demikian, keterbatasan manusia dalam memahami dan mengenali properti ilahi dan manusia secara utuh seharusnya mempunyai implikasi netral yang menyatakan bahwa inkarnasi adalah hal yang mungkin terjadi atau, dengan kata lain, tidak mustahil untuk dilakukan oleh Tuhan.

\section{MENJAWAB TUDUHAN HICK MENGENAI KEPURA-PURAAN ALLAH}

Dalam bukunya, The Metaphor of God Incarnate, Hick menuliskan:

\footnotetext{
${ }^{33}$ Senor, "The Incarnation and the Trinity," 249.
}

\begin{abstract}
For an omnipotent God who consciously refrained from using his limitless power, and who was omniscient but pretended to human ignorance would scarcely count as a human being. He might be declaired by stipulative definition to be so; but from an ordinary point of view he would be a superhuman being. The fears and anxieties to which we are subject, the temptations that afflict us, and the mystery of death that faces us, would all be unreal to him, so that he would live in a different world of meaning from we ordinary mortals. It would be impossible to see in him the perfection of our common human nature, towards which we should strive as his disciples. ${ }^{34}$
\end{abstract}

Pernyataan tersebut mempertanyakan keilahian Yesus yang tidak digunakan karena Ia terus-menerus berperan sebagai manusia super belaka yang juga tidak dapat merasakan pergumulan manusia sesungguhnya. Untuk menjawab tuduhan Hick tentang kepurapuraan Yesus tersebut, penulis akan menggunakan pendekatan Divine Preconscious Model (DPM) $)^{35}$ sebagai alat analisis. Ada empat hal yang akan disoroti oleh penulis terkait isu ini. Pertama, berkaitan dengan pembatasan diri, DPM konsisten dengan ide bahwa Sang Logos ini tahu kehendak Bapa-

\footnotetext{
${ }^{34}$ Hick, The Metaphor of God Incarnate, 62.

${ }^{35}$ Seperti dinyatakan sendiri oleh Andrew Ter Ern Loke bahwa DPM merupakan salah satu model inkarnasi yang memungkinkan (tidak mutlak atau pasti) untuk memahami doktrin inkarnasi secara koheren. Penulis sependapat dengan gagasan Loke yang tertuang dalam model tersebut karena model ini secara internal bersifat koheren. Kendati demikian, seperti halnya pendekatan lainnya (The Two Consciousness Model, The Ontological Kenotic Model, The Divine Subconscious Model), model ini pun tidak lepas dari celah atau kekurangan yang mengundang kritik. Untuk diskusi lebih lanjut, lihat: James M. Arcadi, "Kryptic or cryptic? The Divine Preconscious Model of the Incarnation as a concretenature Christology," De Gruyter 58, no. 2 (2016): 229-243, https://doi.org/10.1515/nzsth-2016-0014. Dalam artikel ini, Arcadi tidak menolak DPM melainkan memberikan masukan perihal posisi Loke yang menganut pandangan concrete-nature yang menurut Arcadi tidak bersesuaian dengan teori dalam DPM ini. Oleh karena itu, ia mengusulkan agar Loke mengambil abstract-nature view atau neoApollinarism untuk menopang pemikiran logis DPM.
} 
Nya dan Ia menuruti segala hal yang diperintahkan kepada-Nya untuk dilakukan dalam keterbatasan-Nya dalam wujud inkarnasi. ${ }^{36}$ Dengan kata lain, meskipun Yesus mempunyai kuasa tak terbatas namun Ia memilih untuk tidak menggunakan kuasa tersebut demi menggenapi rencana BapaNya. Dalam menjalani rencana tersebut, ketika Yesus diharapkan untuk tidak mengakses natur keilahian-Nya, Ia sepenuhnya menggunakan akal budinya dalam kesadaran kemanusiaan-Nya. Sebagai contoh, ketika Yesus mengatakan bahwa Ia tidak mengetahui mengenai kapan masa dan waktunya Ia akan datang lagi ke dunia untuk kedua kalinya (Mat 24:36; Mrk 13:32), Ia mengatakan dengan sungguh karena memang Dia tidak mengetahuinya.

Kedua, berkaitan dengan realitas pencobaan yang dialami Yesus, DPM menyatakan meskipun Yesus mempunyai natur ilahi yang tidak dapat dicobai namun Ia memiliki natur manusiawi yang dapat dicobai sehingga Ia dapat sepenuhnya merasakan pencobaanpencobaan itu sebagai hal yang nyata. Dengan natur manusia ini Yesus dapat merasakan sakit, lapar, haus, lelah dan hal-hal yang dirasakan manusia pada umumnya. Hal ini seperti yang dinyatakan Loke sebagai berikut:

Jesus' divine nature could not be tempted, and if He were to posses only the divine nature, He would be untempt-able. Nevertheless, He did possess a human nature as well: His conscious was human and had the capacity of experiencing physical pain such as hunger. He would thus experience desires such as the desire for food, and hence genuine temptation when such desires conflicted with the will of God. ${ }^{37}$

\footnotetext{
${ }^{36}$ Andrew Ter Ern Loke, A Kryptic Model of the Incarnation (London: Routledge, 2014), 141.

${ }^{37}$ Andrew Ter Ern Loke, "On the coherence of the incarnation: the divine preconscious model," Neue Zeitschrift für systematische Theologie und Religionsphilosophie 51, no. 1 (2009): 62, https://doi.org/10.1515/NZST.2009.004.
}

Selain itu, ketika Yesus menjalani penderitaan salib, Ia juga sungguh-sungguh bergumul dalam ketakutan dan rasa sakit yang Ia tanggung. Setiap hal yang Ia jalani dalam misi inkarnasional ini, Yesus mengandalkan Bapa dan Roh Kudus untuk menopang dan menjalaninya dalam kerapuhan sebagai manusia sejati.

Berkaitan dengan isu kemustahilan Yesus berbuat dosa dalam pencobaan, Collins menyatakan bahwa ketidakmampuan-Nya dalam berbuat dosa secara metafisika tidak menyingkirkan kemungkinan untuk dicobai secara psikologis atau epistemologis. ${ }^{38} \mathrm{Hal}$ tersebut dijelaskan oleh Collins dengan menekankan pentingnya memaknai kata ketidakberdosaan. Menurut pendapatnya, permasalahan tentang dosa tidak hanya dikaitkan dengan kesadaran atau natur seseorang melainkan lebih berkenaan dengan pribadi (person). Oleh karena itu, inkarnasi Allah Anak yang hanya mempunyai satu pribadi yaitu yang bersifat ilahi memang secara $d e$ jure tidak dapat berbuat dosa (impeccable). ${ }^{39}$

Ketiga, berkaitan dengan kematian, adalah benar bahwa Allah tidak dapat mengalami kematian, namun natur manusiawi yang ada di dalam Yesus membuat Yesus mampu mengalami kematian. Secara teknis, hal ini dijelaskan oleh Loke sebagai berikut, "He died when His human mind was separated from His human body. What this separation means is that Jesus' human mind no longer manipulated Jesus' body and obtained sensory input through the sensory organs of Jesus' body at His death, and there was a cessation of vital functions in His body." 40 Dengan kata lain, ketika pikiran Yesus terpisah dari tubuhNya, Ia mengalami kematian di mana pikir-

\footnotetext{
${ }^{38}$ Gerald O'Collins, "The Incarnation: The Critical Issues," dalam The Incarnation: An Interdisciplinary Symposium on the Incarnation of the Son of God, ed. Stephen T. Davis, Daniel Kendall, dan Gerald O'Collins (Oxford: Oxford University Press, 2002), 15.

${ }^{39}$ Ibid., 15.

${ }^{40}$ Loke, "On the coherence of the incarnation: the divine preconscious model," 62.
} 
an Yesus tidak dapat lagi mengatur tubuhNya untuk berfungsi dan juga tidak dapat menerima sensor dari organ-organ tubuh yang ada sehingga pergerakan fungsi vital tubuh secara keseluruhan menjadi terhenti. Fase ini adalah suatu kematian yang umum terjadi juga pada manusia lainnya.

Keempat, pertanyaan yang mungkin muncul adalah: bagaimana dengan keadaan pikiran (state of mind) yang dialami oleh Yesus? Sebagai inkarnasi Allah, Yesus mahatahu dalam pengertian bahwa Ia mengetahui segala proposisi kebenaran dalam preconscious. Hal ini berarti Yesus mempunyai akses untuk menggunakannya akan tetapi karena satu alasan tertentu ia tidak memilih untuk menggunakannya. Salah satu alasan yang nyata dikemukakan dalam Alkitab yang tercatat dalam Ibrani 2:14-17 dan Roma 8:3 adalah bahwa Yesus membatasi diri demi merasakan segala keterbatasan manusia termasuk keterbatasan dalam kesadaran mengetahui kebenaran.

Jadi, dalam kesadaran ilahi-Nya, Yesus tetap benar-benar mengalami segala hal yang terjadi pada-Nya. Loke menggambarkan sebuah ilustrasi yang cukup menjelaskan akan apa yang dialami Yesus. ${ }^{41}$ Yesus diibaratkan sebagai seorang pelari cepat (sprinter) yang kakinya diikatkan pada seorang rekan lainnya. Sebenarnya Yesus dapat dengan mudah melepaskan ikatan tersebut namun Ia memilih untuk membiarkannya demikian dan membatasi diri-Nya. Yesus menjalani tiap lintasan yang harus dilalui secara riil dan itu bukanlah sebuah kepura-puraan.

\section{KOHERENSI DOKTRIN KRISTOLOGI ORTODOKS}

Untuk memahami kristologi ortodoks ada beberapa istilah yang harus dijelaskan terlebih dahulu agar makna dari kata-kata kunci dalam bagian ini dapat dimengerti dengan

\footnotetext{
${ }^{41}$ Loke, A Kryptic Model of the Incarnation, 141.
}

tepat. Ada empat kata utama yang harus dipahami maknanya. Yang pertama, kata "person" yang merujuk pada "an active subjects who does things and to whom things happen" atau subyek aktif yang melakukan sesuatu dan yang kepadanya sesuatu terjadi. ${ }^{42}$ Dengan pengertian tersebut, Kristus dapat dipahami sebagai subyek aktif dari segala sesuatu yang ia kerjakan dan subyek aktif ini merupakan karakter tunggal. Garrett J. De Weesee memberikan pengertian yang lebih komprehensif sebagai berikut, $a$ person is an individual with an appopriately complex and structured set of mental properties, faculties (a natural grouping of capacities) and higher order capacities, unified by internal relations. ${ }^{43}$ Dengan kata lain, person adalah individu dengan seperangkat sifat mental, fakultas (pengelompokan kapa-sitas alami) yang kompleks dan terstruktur dengan tepat, disatukan oleh hubungan internal. Seperangkat sifat mental ini mempunyai tiga properti esensial yaitu kesadaran (meliputi sensasi, pemikiran, kepercayaan, hasrat dan kemauan); kesadaran diri (pengertian akan diri sendiri sebagai subyek dengan kesadaran penuh, kesadaran akan kesadaran diri); relasionalitas (kemampuan untuk berinteraksi dengan individu lainnya dan lingkungan sekitar). ${ }^{44}$

Kedua, kata natur didefinisikan secara singkat sebagai "what a thing is like" atau sesuatu yang menjelaskan keberadaan "being". ${ }^{45} \mathrm{Na}$ tur dari suatu keberadaan kemudian dapat dijelaskan dengan atribut-atribut yang ada di dalamnya. Sebagai contoh, Allah mempunyai satu natur ilahi yang dapat dijelaskan dengan atribut-atribut yang ada pada-Nya seperti omnipotent (mahakuasa), omniscient

\footnotetext{
${ }^{42}$ Stephen J. Wellum, God the Son Incarnate: The Doctrine of Christ (Wheaton: Crossway, 2016), 262.

${ }^{43}$ Garrett J. DeWeese, "One Person, Two Natures: Two Methaphysical Models of the Incarnation," dalam Jesus In Trinitarian Perspective, ed. Fred Sanders dan Klaus Issler (Nashville: B\&H Academic, 2007), 138.

${ }^{44}$ Ibid., 138.

${ }^{45}$ Wellum, God the Son Incarnate: The Doctrine of Christ, 261.
} 
(mahatahu), omnipresent (mahahadir), eternal (kekal), dan lain sebagainya. Contoh lain adalah natur manusiawi yang ada dalam diri manusia yang di antaranya adalah mortal (dapat binasa), limited (terbatas), fragile (rapuh) dan sebagainya. Jadi natur dapat disimpulkan sebagai seperangkat karakteristik yang dimiliki individu yang menentukan sifat individu tersebut. ${ }^{46}$

Ketiga, kata pikiran (mind) merupakan bagian imaterial dari person yang di dalamnya terdapat kapasitas kesadaran, pemikiran, kepercayaan, hasrat, emosi, dan kemauan. Seringkali dalam Alkitab kata "jiwa" (soul) juga merujuk pada keseluruhan atau sebagian dari pikiran. ${ }^{47}$

Keempat, kehendak (will) merupakan kemampuan pikiran untuk menggerakkan person melakukan sesuatu. Dengan lebih spesifik, DeWeese menjelaskan sebagai berikut, " $A$ will is a capacity of the mind by which the person acts to cause something to come about. Often the will causes a bodily action, but sometimes the will causes certain mental states or processes, as when we "will" ourselves to think about something." 48

Dengan definisi kata-kata di atas, penulis akan menjelaskan kaitannya dengan pemahaman doktrin inkarnasi dalam kristologi ortodoks. Dalam metafisika Aquinas, ia menyetujui formulasi kristologi ortodoks mengenai doktrin inkarnasi yang menyebutkan bahwa Kristus mempunyai satu pribadi dengan dua natur di mana pribadi-Nya merupakan pribadi ilahi yang adalah pribadi

\footnotetext{
${ }^{46}$ DeWeese, "One Person, Two Natures: Two Metaphysical Models of the Incarnation," 117. Natur kadangkala diartikan juga sebagai "essence" karena kedua kata tersebut bersinonim. Istilah natur lebih bermakna filosofis dan tidak mempunyai padanan kata dalam Alkitab secara literal walaupun secara tersirat kata tersebut mewarnai kisah-kisah yang tertulis dalam Alkitab.

${ }^{47}$ Ibid., 118.

${ }^{48}$ Ibid.
}

kedua dari Allah Tritunggal. ${ }^{49}$ Ada paradoks yang jelas dalam pribadi Kristus yang mempunyai dua natur yaitu yang ilahi dan yang manusiawi. Walaupun demikian, Aquinas dapat menjelaskan kompleksitas pribadi Kristus ini secara metafisis dengan sangat baik. ${ }^{50}$ Karena Kristus merupakan satu pribadi saja dan satu pribadi merupakan substansi dari jenis tertentu di dalam pribadi tersebut maka pribadi Kristus merupakan substansi gabungan yang terdiri dari jiwa manusia, tubuh dan natur ilahi. Jadi dapat dikatakan bahwa Kristus adalah composite person (pribadi gabungan) di mana pribadi kedua dari Allah Tritunggal yang mempunyai natur ilahi merupakan konstituen (unsur pokok) dari pribadi Kristus. Dengan kata lain, natur manusia dalam diri Yesus, jiwa dan tubuh diambil alih oleh pribadi kedua Trinitas dan disatukan dalam Kristus menjadi a union of person (kesatuan pribadi). Sebagai konsekuensi logis dari penggabungan ini maka komposit baru yang terbentuk merupakan pribadi yang sama dengan pribadi sebelum inkarnasi. ${ }^{51}$

Jadi dapat disimpulkan bahwa pada satu waktu tertentu, Pribadi Kedua dari Trinitas mengambil natur manusia dan menambahkan natur tersebut ke dalam Diri-Nya sendiri yang sudah terdapat natur ilahi sebelumnya. Hal ini tepat seperti teori Aquinas yang menyatakan: "The nature of a material substance is conferred by a substantial form which is an individual and a substantial form is an individual in virtue of configuring matter. So when the second person of the Trinity assumes human nature, he assumes a particular substantial form and the matter it configures." ${ }^{\prime 2}$

\footnotetext{
${ }^{49}$ Eleonore Stump, “Aquinas' Metaphysics of the Incarnation," dalam The Incarnation: An Interdisciplinary Symposium on the Incarnation of the Son of God, ed. Stephen T. Davis, Daniel Kendall, dan Gerald O'Collins (Oxford: Oxford University Press, 2002), 206.

${ }^{50}$ Ibid.

${ }^{51}$ Ibid.

${ }^{52}$ Ibid., 207.
} 
Berdasarkan pemahaman mengenai keutuhan satu pribadi ilahi Yesus dalam inkarnasi dengan dua natur di dalam-Nya, penulis akan menelisik lebih lanjut untuk membuktikan bahwa doktrin inkarnasi ortodoks merupakan doktrin yang koheren. Dalam inkarnasi Sang Logos mempunyai tiga bagian penting yaitu: (1) kesadaran (conscious) manusia; (2) alam bawah sadar (preconscious) yang terdiri dari dua bagian yaitu bagian $\mathrm{A}$ yang memuat segala atribut ilahi dan bagian B yang memiliki atribut manusia; dan (3) tubuh manusia. Dengan demikian, dalam inkarnasi, Sang Logos mempunyai natur manusia yang lengkap yang nyata dalam kepemilikan kesadaran (conscious) manusia, alam bawah sadar manusia (preconscious) dan tubuh manusia. Di sisi lain, pada waktu yang bersamaan, Sang Logos juga memiliki natur ilahi yang utuh dalam salah satu bagian bawah sadar (A) yang terdapat dalam diri inkarnasi. Dengan keberadaan natur ilahi dalam bawah sadar, Sang Logos dalam inkarnasi tetap dapat mempertahankan natur ilahinya dan pada saat yang sama juga tetap menjadi manusia sepenuhnya. Hal ini menunjukkan bahwa pribadi dalam inkarnasi merupakan pribadi yang tunggal yaitu pribadi ilahi yang memiliki satu agen, satu rasionalitas, satu, satu intensionalitas dan satu kesadaran diri (self-consciousness). ${ }^{53}$

Pendekatan ini menyatakan bahwa Logos yang merupakan Pribadi Kedua dari Allah Tritunggal, tidak mempunyai pikiran ilahi yang terbagi dan juga tidak memiliki tubuh pada masa sebelum inkarnasi. ${ }^{54}$ Pada masa inkarnasi, pikiran ilahi terbagi ke dalam dua bagian yaitu conscious (kesadaran) dan preconscious (bawah sadar) di mana atribut ilahi tersimpan di dalam preconscious. Dengan demikian pengetahuan ilahi yang memiliki semua proposisi yang benar, dipindahkan dari conscious ke dalam preconscious. Itulah

\footnotetext{
${ }^{53}$ Loke, "On the coherence of the incarnation: the divine preconscious model," 56.

${ }^{54}$ Ibid.
}

sebabnya Sang Logos tidak mempunyai kesadaran akan segala pengetahuan yang benar dalam area conscious. Conscious yang sudah dikosongkan dari properti ilahi ini, secara simultan memerlukan properti manusia dalam inkarnasi. Jadi model DPM ini menyatakan bahwa Pribadi Kedua dari Allah Tritunggal inilah yang berinkarnasi di dunia dengan menjadi manusia dan menyimpan natur ilahi yang ada di dalam diri-Nya. ${ }^{55}$

Berpijak pada pemahaman di atas, penulis akan menjabarkan tiga poin penting terkait dengan natur Allah yang tampak berkontradiksi dengan natur manusia yang nyata terdapat dalam diri Yesus. ${ }^{56}$ Pertama berkaitan dengan kemahatahuan Yesus sebagai inkarnasi Allah. Omniscience is defined as the knowledge of every true propositions and the belief of no false proposition. ${ }^{57}$ Dengan kata lain, mahatahu didefinisikan sebagai pengetahuan akan setiap proposisi yang benar dan keyakinan bahwa tidak ada proposisi yang salah. Dari pemahaman ini, dapat ditarik dua hal penting berkaitan dengan kemahakuasaan Tuhan. ${ }^{58}$ Yang pertama, untuk memiliki segala pengetahuan mengenai proposisi yang benar tentang $\mathrm{x}$, tidak diperlukan keyakinan tentang $\mathrm{x}$ yang harus dimunculkan dalam kesadaran penuh. Sebagai contoh seorang yang memiliki pengetahuan mengenai akuntasi pada waktu y, tetap memiliki pengetahuan tersebut meskipun pada waktu y

\footnotetext{
${ }^{55}$ Perlu diperhatikan bahwa hal ini berbeda dengan paham Adopsianisme yang menyatakan bahwa pribadi dan kesadaran (consciousness) manusia telah diambil alih oleh Logos yang berinkarnasi (ibid).

${ }^{56}$ Ada banyak atribut ilahi dalam diri Allah seperti omiscient (mahatahu), omnipotent (mahakuasa), omnipresent (mahahadir), immutable (tidak berubah), impeccable (tidak berbuat dosa), eternal (kekal), impassible (tidak dapat menderita), incorporeal (tidak mempunyai tubuh). Kendati demikian, dalam bagian ini penulis hanya akan menjabarkan tiga atribut utama yaitu omniscient (mahatahu), omnipotent (ma-hakuasa) dan omnipresent (mahahadir).

${ }^{57}$ J.P. Moreland and William Lane Craig, Philosophical Foundations For A Christian Worldview (Downers Grove: IVP Academic, 2003), 517.

${ }^{58}$ Loke, "On the coherence of the incarnation: the divine preconscious model," 53-54.
} 
tersebut ia tidak sedang menggunakan pengetahuan itu. Demikianlah kemahatahuan Allah yang terdapat dalam diri Yesus di mana kemahatahuan yang ada pada Yesus tersimpan dalam bawah sadar-Nya, yang dapat diakses sewaktu-waktu. Kendati demikian, untuk alasan tertentu ada kalanya seseorang tidak ingin mengakses pengetahuan tersebut. Sebagai contoh, seseorang mempunyai proposisi yang benar mengenai fakta bahwa binatang peliharaannya telah mati. Dalam kondisi tersebut, orang itu bisa dengan sengaja tidak mau mengakses pengetahuan tersebut dikarenakan hal itu akan menimbulkan kepedihan yang mendalam. Kedua, pengetahuan ilahi yang dimiliki oleh Allah tidak dalam bentuk persepsi di mana pengetahuan itu diperoleh melalui penglihatan. Sebaliknya, pengetahuan ilahi yang dimiliki oleh Allah berbentuk konsep di mana pengetahuan tersebut bersumber dari diri-Nya sendiri. Selain itu, bukanlah hal yang mutlak bagi Allah untuk menempatkan pengetahuan ilahi tersebut dalam kesadaran-Nya (consciousness) karena Ia dapat secara bebas menentukan dan memilih bagian pengetahuan yang ingin ia letakkan dalam bawah sadar-Nya (preconscious). Hal ini seperti yang dinyatakan oleh Loke sebagai berikut:

since having propositional knowledge of a given thing does not require a constant conscious awareness of the true propositions known, and since it is not essential to divinity that God's knowledge be in His conscious awareness, divine omniscience does not require a constant conscious awareness of all the true propositions known. In other words, it is not essential to divinity that God eternally has a complete conscious perspective of everything all at once. It should be noted that if God chooses to limit the extent of His conscious awareness of true propositions, it does not follow that His knowledge would be incomplete or errant. This is because the knowledge of all true propositions would still be in His mind, just not in His conscious, and there is no good reason why He could not ensure that His limited conscious awareness contains only true propositions and no false ones. Neither does it follow that His control of all things would be limited if He chooses to limit His conscious awareness. This is because, just as a human body can perform many physiological functions without requiring its mind be consciously aware of them, God can exercise control of all things through His subconscious without requiring His mind be consciously aware of all things. ${ }^{59}$

Jika demikian, apakah Yesus tetap dapat disebut mahatahu? Seperti dijelaskan di atas bahwa kemahatahuan tidak mempunyai ciri esensial untuk selalu tahu secara sadar segala proposisi kebenaran yang ada. Kendati demikian, kemahatahuan yang tersimpan dalam bawah sadar ini tetap dapat diakses bilamana Yesus memaksudkannya. Hal ini terbukti ketika dalam beberapa peristiwa Yasus mengetahui satu keadaan tertentu tanpa harus melihatnya secara langsung seperti pernyataan bahwa Lazarus telah mati yang tertulis dalam Yohanes 11:11.

Hal kedua berkaitan dengan kemahakuasaan Allah di mana Moreland dan Craig mendefinisikan omnipotence sebagai, "the ability to actualize any state of affairs that is not described by counterfactuals about the free acts of others and that is broadly logically possible for someone to actualize, given the same hard past at $t$ and the same true counterfactuals about free acts of others." 60 Dengan kata lain, kemahakuasaan diartikan sebagai kemampuan untuk mewujudkan segala sesuatu yang bukan kontra-faktual dari tindakan bebas pihak lain dan segala sesuatu ini merupakan tindakan logis yang tidak bertentangan satu dengan yang lain. Dari pengertian ini didapati bahwa kemahakuasaan tidak mensyaratkan adanya kesadaran dalam

\footnotetext{
${ }^{59}$ Ibid., 54 .

${ }^{60}$ Moreland and Craig, Philosophical Foundations For A Christian Worldview, 527-529.
} 
aktualisasinya. Kemahakuasaan juga tidak harus selalu hadir dalam setiap tindakan person tersebut. Hal ini berarti person yang mempunyai kemahakuasaan itu bebas menentukan dalam hal apakah ia menunjukkan kemahakuasaannya dan dalam hal ini membatasi kuasanya.

Kemahakuasaan Yesus juga tidak mewajibkan Yesus untuk selalu menggunakan kemahakuasaan-Nya dalam setiap keadaan melainkan Yesus mempunyai pilihan bebas dalam menggunakannya. Dengan demikian, dalam kemahakuasaan-Nya, Yesus tetap dapat berperan sebagai manusia seutuhnya dengan melakukan segala aktivitas-Nya tanpa harus menggunakan kemahakuasaan-Nya. Itulah sebabnya dalam wujud inkarnasi, meskipun Yesus adalah Allah yang mahakuasa namun pada saat yang bersamaan Dia juga adalah manusia yang dapat merasakan lelah dan sakit.

Selain itu, berkaitan dengan kemahakuasaan-Nya, Yesus juga sanggup terus menopang dunia ini dalam inkarnasi seperti yang dinyatakan dalam Ibrani 1:3 yang menyatakan, "Ia adalah cahaya kemuliaan Allah dan gambar wujud Allah dan menopang segala yang ada dengan firman-Nya yang penuh kekuasaan." Dengan pengertian bahwa kemahakuasaan tidak mensyaratkan adanya kesadaran (conscious) dalam penggunaannya maka dapat dipahami secara rasional bahwa Yesus tetap menopang dunia ini dengan kuasanya dalam bawah sadar-Nya. Hal ini dapat dijelaskan secara sederhana dengan ilustrasi tubuh manusia yang tiap-tiap organnya dapat bekerja dan berfungsi dengan baik tanpa adanya consciousness dari pribadi yang memiliki tubuh tersebut.

Hal ketiga berkaitan dengan kemahahadiran Yesus. Mahahadir dipahami sebagai "the knowledge of and the ability to be causally active at every point in space." ${ }^{61} \mathrm{Hal}$ ini berarti

\footnotetext{
${ }^{61}$ Ibid., 509-511.
}

kemahahadiran merupakan pengetahuan dan kemampuan yang aktif secara kasual pada setiap titik dalam ruang. Permasalahan dengan keilahian Yesus adalah bahwa Yesus tidak bersifat mahahadir di mana Yesus terperangkap dalam tubuh jasmani-Nya yang terbatas oleh ruang dan waktu. Lalu bagaimana menjelaskan kemahahadiran Yesus? Klaim mengenai kemahahadiran Yesus tidak bisa dilepaskan dari definisi mahahadir di atas. Dalam pemahaman DPM, Yesus dikatakan mahahadir karena Ia secara kasual aktif dengan kemahatahuan dan kemahakuasaan yang ada pada-Nya. Hal ini dapat diperjelas dengan sebuah ilustrasi yang diberikan oleh Loke sebagai berikut. ${ }^{62}$ Jika seseorang yang berada di Yunani berdoa kepada Yesus untuk meminta perlindungan, maka Yesus yang walaupun berada di Palestina dapat mengetahui hal tersebut dalam bawah sadar ilahi-Nya dan dapat menjawab doa orang tersebut. Hal ini dapat dimengerti dalam dua kemungkinan. Pertama, Sang Logos dalam inkarnasi-Nya telah ditetapkan untuk memampukan bawah sadar ilahi-Nya menyadari akan doa dari orang tersebut ketika orang itu berdoa kepada-Nya dan Ia dapat memilih untuk menggunakan kemahakuasaan-Nya yang juga terdapat dalam bawah sadar ilahi untuk merespon doa tersebut atau Ia juga dapat meminta Allah Bapa dan Allah Roh Kudus untuk mewakili-Nya dalam menjawab doa orang tersebut. Kemungkinan yang kedua, Sang Logos ditetapkan untuk dapat menjawab doa orang tersebut dalam bawah sadar ilahi-Nya tanpa melewati kesadaran yang ada pada-Nya. ${ }^{63}$ Dengan dua kemungkinan tersebut, setiap orang dapat terhubung dengan Sang Logos meskipun secara fisik Sang Logos terbatas dalam tubuh jasmani.

Jadi karena Yesus memiliki kemahatahuan dalam segala proposisi yang benar dan Ia juga memiliki kemahakuasaan dalam segala

\footnotetext{
${ }^{62}$ Loke, A Kryptic Model of the Incarnation, 135.
} 
sesuatu maka dapat dikatakan bahwa Yesus mempunyai kemampuan untuk secara aktif terlibat dalam setiap poin dalam ruang lingkup dunia ini. Dengan pengertian bahwa mahahadir berarti secara kasual aktif terlibat dalam setiap poin dalam ruang lingkup dunia maka Yesus merupakan pribadi yang mahahadir. Kemahahadiran-Nya yang terletak dalam bawah sadar-Nya tidak dibatasi oleh ruang dan waktu karena bawah sadar bersifat imaterial dan tidak dibatasi pada keberadaan fisik-Nya.

\section{KESIMPULAN}

Identitas Yesus Kristus sebagai inkarnasi Allah Anak, Pribadi Kedua dari Allah Tritunggal merupakan hal yang sangat krusial dalam kekristenan. Natur ganda yang disandangNya kerap kali menimbulkan kebingungan dan pertanyaan di dalam memahaminya. Oleh karena itu secara sistematik, Konsili Nicaea dan Konsili Chalcedon merumuskan identitas Yesus dalam doktrin inkarnasi ortodoks berdasarkan kebenaran Kitab Suci. Kendati demikian rumusan tersebut ternyata justru menuai banyak kritik dan penolakan. Salah satu tokoh yang menolak rumusan tersebut adalah John Hick.

Isu utama yang menjadi perhatian penulis berkaitan dengan pandangan Hick adalah tuduhan inkoherensi yang dilayangkan oleh Hick terhadap doktrin inkarnasi ortodoks. Konsep dwinatur yang ada dalam doktrin inkarnasi ortodoks dianggap olehnya berkontradiksi dan tidak dapat dipahami dengan logika. Menanggapi hal tersebut penulis mengungkap kesalahan logika yang berdasarkan pada konsep statement of identity. Penulis menunjukkan bahwa penalaran yang paling tepat terkait dengan konsep dwinatur dalam inkarnasi adalah dengan menggunakan logika relativitas identitas dan ciri alamiah. Logika relativitas identitas menyatakan bahwa kesamaan dari dua obyek yang dianggap identik tidak mensyaratkan kesamaan seluruh atribut yang ada pada kedua obyek tersebut melainkan hanya pada ciri esensial saja. Dalam konteks inkarnasi, logika tersebut dapat diterapkan dengan menyatakan bahwa banyak sifat manusia yang secara harafiah tidak dapat dinyatakan sebagai sifat Allah dan banyak pula karakteristik ilahi yang tidak dapat begitu saja dimiliki oleh manusia manapun. Hal ini diperjelas dengan konsep ciri alamiah yang menyatakan bahwa kemanusiaan Yesus yang berbeda dari manusia pada umumnya tidak bisa membuktikan bahwa Yesus bukan manusia karena meskipun manusia mempunyai ciri kemanusiaan tertentu yang dimiliki manusia pada umumnya namun tidak semua manusia memiliki ciri tersebut secara penuh.

Dari pemaparan di atas dapat dinyatakan bahwa doktrin kristologi ortodoks adalah doktrin yang koheren karena tidak bertentangan dengan logika dan dapat dipahami dengan jelas sesuai dengan kebenaran Kitab Suci. Persoalan pemahaman mengenai dwinatur yang ada dalam diri Kristus bukanlah hal yang kontradiktif karena keduanya meskipun berbeda namun dapat tetap bersanding secara harmonis dalam inkarnasi Allah.

Selanjutnya dalam inkarnasi Allah Anak sebagai manusia, Hick juga meragukan keilahian Yesus di mana Yesus dituduh terusmenerus berpura-pura menjadi manusia. Dengan demikian menurut Hick, Yesus tidak pernah dapat merasakan segala pergumulan manusia dengan sungguh melalui apa yang ia alami. Untuk menanggapi hal ini penulis menggunakan pendekatan DPM untuk menguraikan pembatasan diri yang dilakukan Yesus. DPM menjelaskan bahwa dalam kemahakuasaan Yesus sebagai Allah, Ia tetap menundukkan diri-Nya dalam ketaatan kepada kehendak Bapa-Nya. Itulah sebabnya, dalam misi inkarnasional yang Ia jalani, Yesus mengandalkan Allah Bapa dan Allah Roh Kudus dalam kerapuhan-Nya sebagai manusia sejati. Dengan demikian, Yesus mengalami dan merasakan dengan sesungguhnya semua pergumulan manusia yang 
terjadi pada-Nya dan hal itu bukanlah sebuah kepura-puraan.

Kemudian, sebagai pembelaan penulis terhadap koherensi doktrin inkarnasi ortodoks, penulis memaparkan kajian logika dengan pendekatan DPM. Berdasarkan metafisika Aquinas yang memformulasikan kompleksitas pribadi Kristus secara metafisis, penulis telah menjelaskan koherensi konsep dwinatur Yesus dengan menganalisa tiga atribut ilahi dalam diri Yesus yang secara esensial tidak bertentangan dengan natur kemanusiaan Yesus. DPM menjelaskan dengan gamblang bahwa tiga atribut ilahi Yesus yaitu, omniscient, omnipotent dan omnipresent tersimpan dalam bawah sadar ilahi-Nya. Kepemilikan bawah sadar ilahi tidak menjadikan kepemilikan natur manusiawi menjadi mustahil terjadi dalam inkarnasi karena kepemilikan bawah sadar ilahi tidak berkontradiksi dengan properti esensial dari manusia. Demikian juga kepemilikan kesadaran ilahi bukanlah ciri esensial dari natur ilahi. Yang merupakan hal esensial untuk dimiliki natur ilahi adalah atribut seperti omniscient, omnipotent, omnipresent dan sebagainya. Atributatribut ilahi tersebut juga tidak mutlak harus berada dalam area kesadaran untuk diakui keilahiannya. Meskipun atribut-atribut tersebut terletak dalam area bawah sadar, hal itu tidak menjadikan Pribadi yang berinkarnasi tidak memiliki pengetahuan yang lengkap maupun mengurangi kuasa yang ada padaNya. Dengan demikian, peletakan natur ilahi dalam area bawah sadar tidak pernah mengurangi keilahian dan kemanusiaan Yesus.

Dari pemaparan di atas dengan keyakinan penuh, penulis menyatakan bahwa kekristenan tidak perlu memberikan artikulasi ulang terhadap doktrin inkarnasi ortodoks yang mengakui keilahian Yesus karena terbukti nyata bahwa Yesus adalah Allah. Ia adalah inkarnasi Allah Anak yang mempunyai dua natur yaitu natur manusiawi dan natur ilahi. Dua natur yang tampak kontradiktif ini dapat menyatu dalam diri inkarnasi
Yesus Kristus secara harmonis. Dengan demikian, inkarnasi tidak pernah dimaksudkan dalam bentuk metaforis apalagi mitologis seperti yang diusulkan oleh Hick.

\section{DAFTAR KEPUSTAKAAN}

Arcadi, James M. "Kryptic or cryptic? The Divine Preconscious Model of the Incarnation as a concrete-nature Christology." De Gruyter 58, no. 2 (2016): 229 243. https://doi.org/10.1515/nzsth-20160014.

Case-Winters, Anna. "Incarnation: In What Sense Is God Really 'With Us'?” European Journal for Philosophy of Religion 11, no. 1 (2019).

DeWeese, Garrett J. "One Person, Two Natures: Two Metaphysical Models of the Incarnation." Dalam Jesus In Trinitarian Perspective, diedit oleh Fred Sanders dan Klaus Issler, 114-155. Nashville: B\&H Academic, 2007.

Garcia, Hidalgo B. "Pluralisme Agama dan Paradoks Kasih Karunia: Mengenai Pemakaian Kristologi Donald Baillie oleh John Hick." Veritas: Jurnal Teologi dan Pelayanan 7, no. 2 (Oktober 2006): 149-164, https://doi.org/10.36421/veritas. v7i2.175.

Hick, John. "Incarnation and Atonement: Evil and Incarnation." Dalam Incarnation and Myth: The Debate Continued. Grand Rapids: Eerdmans, 1979.

- "Jesus and the World Religion." Dalam The Myth of God Incarnate. London: SCM, 1977.

- The Metaphor of God Incarnate. Louisville: Westminster John Knox, 1993.

Loke, Andrew Ter Ern. A Kryptic Model of the Incarnation. London: Routledge, 2014.

. "On the coherence of the incarnation: the divine preconscious model." Neue Zeitschrift für systematische Theologie und Religionsphilosophie 51, 
no. 1 (2009): 50-63. https://doi.org/ 10.1515/NZST.2009.004.

Moreland, J.P., dan William Lane Craig. Philosophical Foundations For A Christian Worldview. Downers Grove: IVP Academic, 2003.

Morris, Thomas V. The Logic of God Incarnate. Eugene: Wipf \& Stock, 2001.

O'Collins, Gerald. "The Incarnation: The Critical Issues." Dalam The Incarnation: An Interdisciplinary Symposium on the Incarnation of the Son of God, diedit oleh Stephen T. Davis, Daniel Kendall, dan Gerald O'Collins, 1-27. Oxford: Oxford University Press, 2002.

Pranoto, Minggus. "Perkembangan Doktrin Inkarnasi Kristus: Misteri Iman dan
Dasar Keselamatan Manusia.” Jurnal Abdiel 6 (Oktober 2015): 88-105.

Senor, Thomas D. "The Incarnation and the Trinity." Dalam Reason for the Hope Within, diedit oleh Michael J. Murray, 238-260. Grand Rapids: Eerdmans, 1999.

Stump, Eleonore. “Aquinas' Metaphysics of the Incarnation." Dalam The Incarnation: An Interdisciplinary Symposium on the Incarnation of the Son of God, diedit oleh Stephen T. Davis, Daniel Kendall, dan Gerald O'Collins, 197-220. Oxford: Oxford University Press, 2002.

Wellum, Stephen J. God the Son Incarnate: The Doctrine of Christ. Wheaton: Crossway, 2016. 